\title{
Heterogeneity of Thymidine Kinase Among Species of Mycoplasma and Acholeplasma
}

\author{
WESLEY M. SUGINO \\ Department of Medical Microbiology, School of Medicine, University of California-Irvine, \\ Irvine, California 92717
}

\begin{abstract}
The thymidine kinase activities present in nine strains (including four type strains and one neotype strain) of nine species of the genus Mycoplasma and two strains (including one type strain) of two species of the genus Acholeplasma were characterized with respect to migration in polyacrylamide gels and isoelectric point as determined by electrofocusing. There was a marked heterogeneity in the enzymes, not only between the two genera but also within each genus.
\end{abstract}

Previous investigators have shown that certain mycoplasmas have thymidine kinase (TK) activity $(7,9)$, and it has been suggested that these organisms might use the scavenger pathway to supply thymidine nucleotides for deoxyribonucleic acid synthesis.

The purpose of this study was to examine other mycoplasmas and some acholeplasmas for the presence of TK activity and to characterize the TKs by polyacrylamide gel electrophoresis and isoelectric focusing.

\section{MATERIALS AND METHODS}

The sources and designations of the strains of $M y$. coplasma and Acholeplasma used in this study are listed in Table 1.

Cells were grown at $37^{\circ} \mathrm{C}$ in $40 \mathrm{ml}$ of a medium consisting of beef heart infusion supplemented with $20 \%$ whole horse serum, $10 \%$ yeast extract, $100 \mathrm{U}$ of penicillin per $\mathrm{ml}$, and $0.002 \%$ phenol red. Growth of the organisms and possible contamination were checked by inoculating $0.1 \mathrm{ml}$ of the broth culture onto PPLO agar plates supplemented as described above. The growth from a $40-\mathrm{ml}$ broth culture was harvested by centrifugation of the culture for $30 \mathrm{~min}$ at 20,000 $\times g$ in a Ti 60 rotor in an L5-50 Beckman ultracentrifuge; the pellet was then resuspended in 1 $\mathrm{ml}$ of $0.1 \mathrm{M}$ tris(hydroxymethyl)aminomethane-hydrochloride ( $\mathrm{pH} 8.0$ ) containing $0.5 \%$ Triton X-100. The resulting lysate was centrifuged for $15 \mathrm{~min}$ at $35,000 \times g$, and $100 \mu \mathrm{l}$ of the supernatant was assayed for TK activity. TK activity was assayed as described by Munyon et al. (3). The $200-\mu l$ TK reaction mixture consisted of $0.07 \mathrm{M} \mathrm{KCl}, 1.3 \mathrm{mM}$ 2-mercaptoethanol, $2 \mathrm{mM} \mathrm{MgCl}_{2}, 4 \mathrm{mM}$ adenosine triphosphate, $4.5 \mu \mathrm{Ci}$ of $\left[{ }^{3} \mathrm{H}\right]$ thymidine $(60 \mathrm{Ci} / \mathrm{mmol}$; New England Nuclear Corp.), $0.1 \mathrm{M}$ tris(hydroxymethyl)aminomethane-hydrochloride ( $\mathrm{pH} 8.0)$, and $100 \mu \mathrm{l}$ of the supernatant from the centrifuged lysate. This was allowed to react for $20 \mathrm{~min}$ at $38^{\circ} \mathrm{C}$. The reaction was stopped with 35 $\mu \mathrm{l}$ of $50 \%$ trichloroacetic acid, and $30-\mu \mathrm{l}$ portions were spotted onto DE-81 filters. After drying, the filters were washed four times in $0.001 \mathrm{M}$ ammonium formate buffer ( $\mathrm{pH} 3.6$ ), four times in water, and once in $95 \%$ ethanol. The papers were dried and counted in $5 \mathrm{ml}$ of toluene scintillation fluid; $5 \%$ polyacrylamide gel electrophoresis and isoelectric focusing were then run on the lysate supernatants which contained TK activity.

Electrophoresis was carried out as described by Munyon et al. (3); $5 \%$ polyacrylamide was used for the separating gels. Electrophoresis was carried out in 7 $\mathrm{cm}$ gel columns at $4^{\circ} \mathrm{C}$ for approximately $2 \mathrm{~h}$. A 100 $\mu \mathrm{l}$ portion of the enzyme lysate plus $20 \mu \mathrm{l}$ of $50 \%$ glycerol and $0.2 \%$ bromophenol blue were added to the top of the gel. A constant current power supply was used, and this was set at $2 \mathrm{~mA} / \mathrm{gel}$. The electrophoretic migration was discontinued when the bromophenol blue band was approximately $3 \mathrm{~mm}$ from the anode end of the tube. The gels were removed from the tube and frozen for $15 \mathrm{~min}$ at $-70^{\circ} \mathrm{C}$. Gel slices $(2 \mathrm{~mm})$ were taken, placed on $0.7-\mathrm{cm}$ squares of DE-81 paper saturated with $20 \mu$ l of TK reaction mixture, and incubated for $4 \mathrm{~h}$ at $37^{\circ} \mathrm{C}$ in a humidified atmosphere. The TK reaction mixture consisted of $0.1 \mathrm{M}$ maleatetris(hydroxymethyl)aminomethane buffer ( $\mathrm{pH} 6.5$ ), $0.025 \mathrm{M} \mathrm{KCl}, 0.02 \mathrm{M} \mathrm{MgCl}_{2}, 0.0014 \mathrm{M} 2$-mercaptoethanol, $0.01 \mathrm{M}$ adenosine triphosphate, and $0.1 \mathrm{mCi}$ of $\left[{ }^{3} \mathrm{H}\right]$ thymidine (specific activity, $60 \mathrm{Ci} / \mathrm{mmol}$ ) per gel column. After incubation, the papers were washed four

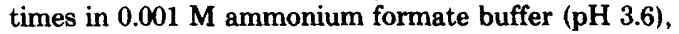
four times in water, and once in 95\% ethanol. The papers were dried, placed in vials containing $5 \mathrm{ml}$ of toluene scintillation fluid, and counted.

The isoelectric focusing gel solution consisted of the following: 26\% (vol/vol) acrylamide-bis-acrylamide stock $(28 \%$ [wt/vol] acrylamide plus $1.62 \%$ [wt/vol] bis-acrylamide); $3 \%$ (vol/vol) ampholytes, $\mathrm{pH} 3.5$ to 10 (LKB); $2 \%$ (vol/vol) ampholytes, $\mathrm{pH} 7$ to $9 ; 48.7 \%$ (vol/vol) glycerol (40\% solution); $0.2 \%$ (vol/vol) riboflavin $\left(4 \mathrm{mg} / 100 \mathrm{ml}\right.$ ); $0.13 \%$ (vol/vol) $N, N, N^{\prime}, N^{\prime}$-tetramethylethylenediamine; and $0.26 \%$ (vol/vol) ammonium persulfate $(100 \mathrm{mg} / \mathrm{ml})$. This solution was placed in gel tubes and photopolymerized for $30 \mathrm{~min}$. Gel columns $(10 \mathrm{~cm})$ were run with $0.1 \mathrm{~N} \mathrm{NaOH}$ as the upper electrode buffer and $0.01 \mathrm{~N} \mathrm{H}_{3} \mathrm{PO}_{4}$ as the lower electrode buffer. The gels were overlaid with $0.05 \mathrm{ml}$ of a solution consisting of the following: 0.06 $\mathrm{ml}$ of ampholytes, $\mathrm{pH} 3.5$ to $10 ; 0.04 \mathrm{ml}$ of ampholytes, $\mathrm{pH} 7$ to $9 ; 0.95 \mathrm{ml}$ of $40 \%$ (vol/vol) glycerol; and $0.4 \mathrm{ml}$ of water. The gels were then prerun for $15 \mathrm{~min}$ at 200 
TABLE 1. Mycoplasma and Acholeplasma strains used in this study

\begin{tabular}{lll}
\hline $\begin{array}{c}\text { Serological type } \\
\text { or species }\end{array}$ & \multicolumn{1}{c}{ Strain } & \multicolumn{1}{c}{ Source } \\
\hline$M$. arginini & $\begin{array}{c}\text { Tissue culture } \\
\text { isolate }\end{array}$ & E. Stanbridge \\
$M$. arthritidis & PG6 $^{a}$ & E. Stanbridge \\
$M$. fermentans & PG18 $^{b}$ & E. Stanbridge \\
$M$. gallinarum & PG16 $^{h}$ & E. Stanbridge \\
$M$. hominis & PG21 $^{b}$ & E. Stanbridge \\
$M$. hyorhinis & ESCA-1 & E. Stanbridge \\
$M$. orale type 1 & ESE-1 & E. Stanbridge \\
$M$. pulmonis & JB & J. Galpin \\
M. salivarium & PG20 & E. Stanbridge \\
A. laidlawii & PG8 & E. Stanbridge \\
A. granularum & No designation & G. Kenny via E. \\
& & Stanbridge \\
\hline
\end{tabular}

a Neotype strain.

${ }^{b}$ Type strain.

$\mathrm{V}$ (constant voltage), for $30 \mathrm{~min}$ at $300 \mathrm{~V}$, and for $1 \mathrm{~h}$ at $400 \mathrm{~V}$. After prerunning, $55 \mu \mathrm{l}$ of the enzyme lysate plus $8 \mu$ l of ampholytes, pH 3.5 to $10,6 \mu \mathrm{l}$ of ampholytes, $\mathrm{pH} 7$ to $9,130 \mu \mathrm{l}$ of $100 \%$ glycerol, and sheep erythrocyte hemoglobin were layered below the overlay buffer with a Hamilton syringe. The gels were run in a cold room $\left(4^{\circ} \mathrm{C}\right)$ for $15 \mathrm{~h}$ at $400 \mathrm{~V}$ and then for 1 $h$ at $600 \mathrm{~V}$. The gels were removed, frozen, sliced, and assayed as described above for the $5 \%$ polyacrylamide gels. Slices $(4 \mathrm{~mm})$ from the control gel were placed in $1 \mathrm{ml}$ of water and shaken for $2 \mathrm{~h}$ at $4^{\circ} \mathrm{C}$, and the $\mathrm{pH}$ was determined with a Beckman Phasar-I digital pH meter.

\section{RESULTS AND DISCUSSION}

Figure 1A shows the electrophoretic profiles of Mycoplasma pulmonis strain JB and Mycoplasma arthritidis $\mathrm{PG} 6 \mathrm{TKs}$, and Fig. 1B shows the electrophoretic profiles of the Acholeplasma granularum strain and Acholeplasma laidlawii PG8 TKs. The $M$. pulmonis JB TK had an $R_{f}$ (migration relative to bromophenol blue) value of less than 0.1, whereas $M$. arthritidis PG6 TK had an $R_{f}$ value which ranged from 0.14 to 0.21 . The $A$. granularum strain TK had an $R_{f}$ value between 0.34 and 0.37 , and the $A$. laidlawii PG8 TK $R_{f}$ ranged from 0.41 to 0.47 . Polyacrylamide gel electrophoreses were also run on lysate supernatants from strains of Mycoplasma arginini, $M$. fermentans, $M$. gallinarum, $M$. hom . inis, $M$. hyorihinis, $M$. orale, and $M$. salivarium (Table 2). The TK $R_{f}$ values for these different strains varied over a wide range; there were even differences within each genus (i.e., Mycoplasma and Acholeplasma).

The results of the isoelectric focusing gel determinations for $A$. laidlawii PG8 and $M$. ar. thritidis PG6 TKs are shown in Fig. 2A and B, respectively. The isoelectric point (pI) for $A$. laidlawii PG8 TK was between 7.0 and 7.2, and that for $M$. arthritidis PG6 TK was $\geq 7.9$. The pI values for these and the other strains are shown in Table 2. The two Acholeplasma strains had similar pI values (approximately 7.2 ), which were quite different from those of the Mycoplasma strains. The TK activities of $M$. arthritidis PG6 and the other mycoplasmas remained at the tops of the isoelectric focusing gels; therefore, gels with higher $\mathrm{pH}$ ranges must be used to determine accurately the pI values of these strains.

The heterogeneity of the TKs found in different species of Mycoplasma is not surprising considering the lack of deoxyribonucleic acid homology among them, as determined by McGee

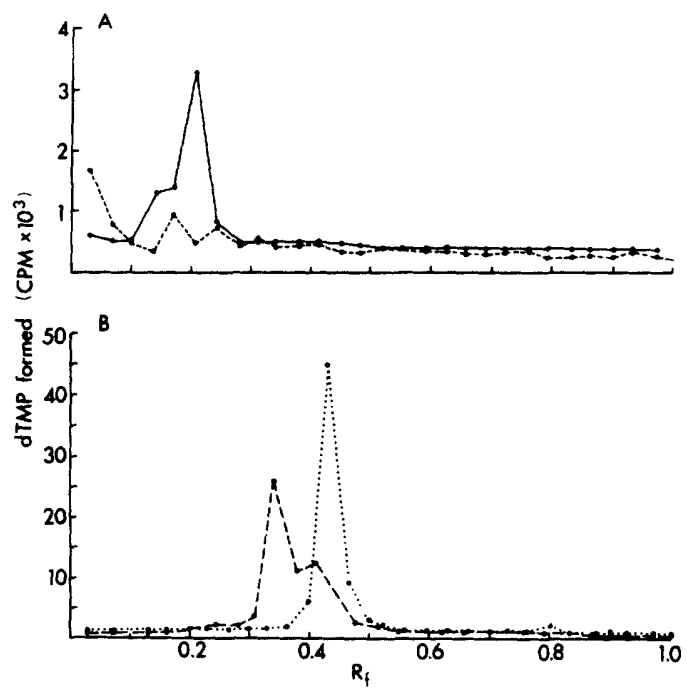

Fig. 1. Polyacrylamide gel electrophoresis of $M y$. coplasma and Acholeplasma TK activities. (A) Dashed line, $M$. pulmonis; solid line, $M$. arthritidis. (B) Dashed line, A. granularum; dotted line, A. laidlawii. dTMP, Deoxyribosylthymine monophosphate.

TABLE 2. $R_{f}$ values and isoelectric points of TKs from strains of Mycoplasma and Acholeplasma

\begin{tabular}{lcc}
\hline \multicolumn{1}{c}{ Strain } & $R_{f}^{\prime \prime}$ & $\mathrm{pI}$ \\
\hline$M$. arginini tissue culture & $0.3-0.33$ & $\geq 8.0$ \\
$\quad$ isolate & & \\
$M$. arthritidis PG6 & $0.14-0.21$ & $\geq 7.9$ \\
$M$. fermentans PG18 & $0.2-0.33$ & $\geq 8.0$ \\
$M$. gallinarum PG16 & 0.5 & \\
$M$. hominis PG21 & $0.36-0.4$ & $\geq 7.5$ \\
$M$. hyorhinis ESCA-1 & $0.1-0.2$ & $\geq 7.8$ \\
$M$. orale type 1 ESE-1 & $0.2-0.27$ & $\geq 7.7$ \\
$M$. pulmonis JB & $<0.1$ & \\
M. salivarium PG20 & $0.3-0.38$ & $\geq 8.0$ \\
A. laidlawii PG8 & $0.41-0.47$ & $7.0-7.2$ \\
A. granularum & $0.34-0.37$ & $7.2-7.5$ \\
\hline
\end{tabular}

a As determined by $5 \%$ polyacrylamide gel electrophoresis. 


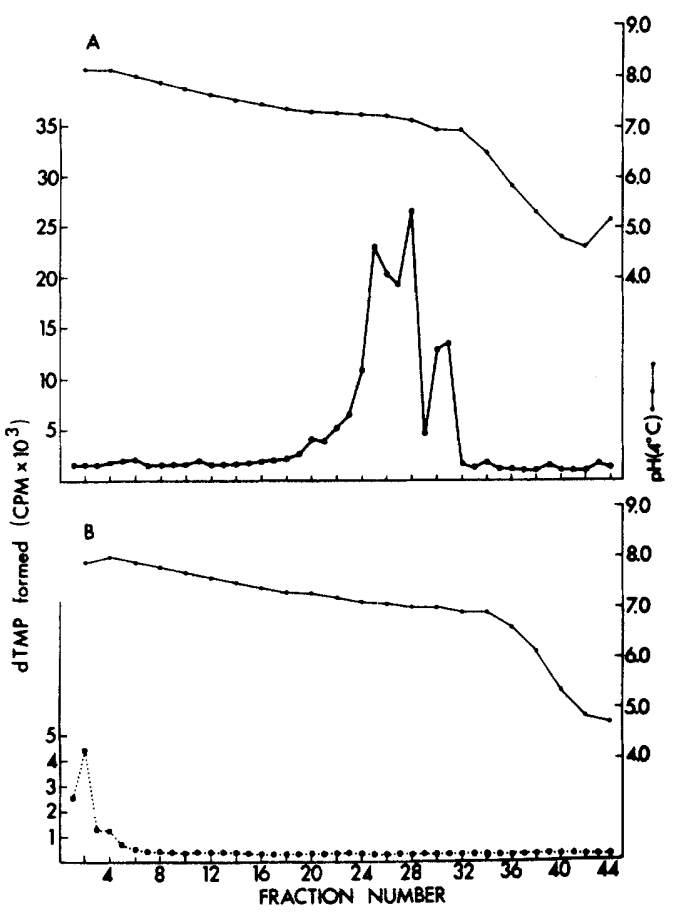

FIG. 2. Isoelectric focusing profiles of TKs. (A) Bottom curve, A. laidlawii TK profile. (B) Bottom curve, $M$. arthritidis $T K$ profile. The top curves in both (A) and (B) are the $p H$ profiles of the gels. dTMP, Deoxyribosylthymine monophosphate.

et al. (2) and Reich et al. $(5,6)$. There were no Mycoplasma species examined in this study which did not contain TK activity. Differences in electrophoretic mobility of hypoxanthine-guanine phosphoribosyl transferase activity between Mycoplasma species have already been demonstrated by Stanbridge et al. (8) and Van Diggelen et al. (10).

TK, together with other enzyme activities (such as hypoxanthine-guanine phosphoribosyl transferase, HGPRT), is frequently studied in cultures of mammalian cells. The cryptic contamination of tissue cultures by mycoplasmas not readily propagated on artificial culture media is a proven problem in such studies. The heterogeneity of the TKs from mycoplasmas, although of some taxonomic interest, must also be considered in such studies as those dealing with the selection of mutant phenotypes of tissue culture cells or the biochemical transformation of cells by viruses $(1,4)$.

\section{ACKNOWLEDGMENTS}

I thank David T. Kingsbury and Eric J. Stanbridge for their helpful suggestions and critical review of this manuscript. I especially thank E. J. Stanbridge for providing cultures of the strains of the different species of Mycoplasma and Leslie Thorpe for her excellent technical assistance.

This work was supported by Public Health Service contract NO 1 CP 53560 from the Virus Cancer Program, National Cancer Institute, by American Cancer Society Institutional grant IN-120, and by a grant from the Kroc Foundation to David T. Kingsbury.

\section{REPRINT REQUESTS}

Address reprint requests to: Dr. Wesley $M$. Sugino, Department of Medical Microbiology, University of California, Irvine, CA 92717.

\section{LITERATURE CITED}

1. Bacchetti, S., and F. L. Graham. 1977. Transfer of the gene for thymidine kinase to thymidine kinase-deficient human cell by purified herpes simplex viral DNA. Proc. Natl. Acad. Sci. U.S.A. 74:1590-1594.

2. McGee, Z. A., M. Rogul, and R. G. Wittler. 1967. Molecular genetic studies of relationships among mycoplasma, L-forms and bacteria. Ann. N.Y. Acad. Sci. 143:21-30.

3. Munyon, W., R. Buchsbaum, E. Paoletti, J. Mann, E. Kraiselburd, and D. Davis. 1972. Electrophoresis of thymidine kinase activity synthesized by cells transformed by herpes simplex virus. Virology 49:683-689.

4. Munyon, W., E. Kraiselburd, D. Davis, and J. Mann. 1971. Transfer of thymidine kinase to thymidine kinaseless $\mathrm{L}$ cells by infection with ultraviolet-irradiated herpes simplex virus. J. Virol. 7:813-820.

5. Reich, P. R., N. L. Somerson, C. J. Hybner, R. M. Chanock, and S. M. Weissman. 1966. Genetic differentiation of nucleic acid homology. J. Bacteriol. 92:302310.

6. Reich, P. R., N. L. Somerson, J. A. Rose, and S. M. Weissman. 1966. Genetic relatedness among mycoplasmas as determined by nucleic acid homology. J. Bacteriol. 91:153-160.

7. Russell, W. C. 1966 . Alterations in the nucleic acid metabolism of tissue culture cells infected by mycoplasmas. Nature (London) 212:1537-1540.

8. Stanbridge, E. J., J. A. Tischfield, and E. L. Schneider. 1975. Appearance of hypoxanthine guanine phosphoribosyl transferase activity as a consequence of mycoplasma contamination. Nature (London) 256:329331.

9. Stock, D. A., and G. A. Gentry. 1971. Thymidine metabolism in Mycoplasma hominis. J. Gen. Microbiol. 65:105-107.

10. Van Diggelen, O. P., G. J. McGarrity, and S.-I. Shin. 1978. Endogenous HPRT activity in mycoplasmas isolated from cell cultures. In Vitro 14:734-739. 